\title{
Effects of Early Development of Hyponatremia on In-hospital Outcomes in Acute ST- Elevation Myocardial Infarction
}

\author{
Mirza Md. Nazrul Islam¹, Md. Abdul Kader², H I Lutfor Rahman Khan ${ }^{3}$, Mahmood Hasan Khan²
}

\begin{abstract}
:
Background: Coronary heart disease is a major cause of death and is a global health problem and reaching epidemic in both developed and as well as in developing countries. In patients with acute myocardial infarction baroreceptor mediated hormonal activation has a prognostic value. Clinical importance of hyponatraemia in ST-elevation acute myocardial infarction has not been fully understood. Hyponatremia which developed in early phase of AMI has been recently advocated as an important prognostic factor in several studies. Objectives: The aim of the study was to investigate the impact of hyponatremia on in-hospital outcomes in patients with ST-elevation acute myocardial Infarction treated by thrombolysis. Methods: Hyponartaemia was defined as a sodium concentration $<135 \mathrm{mmol} / \mathrm{L}$. Hyponatremia which developed at 72 hours after admission was defined as early developed hyponatraemia. This study is a prospective observational study. A purposive sampling technique was used to select the sample. In this study data on 100 patients with ST-elevation acute myocardial infarction were analyzed. This study was done in the department of Cardiology Mymensingh Medical College Hospital from July 2014 to June 2015. Patients admitted in the department of Cardiology MMCH with acute STelevation myocardial infarction and treated with thrombolysis were evaluated for serum sodium level at admission and at $\mathbf{7 2}$ hours after admission. Total 100
\end{abstract}

patients were studied. Fifty patients with hyponatraemia were Group-I and fifty patients with normal sodium level were Group-II. Then the in-hospital outcome variables were analyzed. Results: Among the study population $85 \%$ were male and $15 \%$ were female. Age range was 25 years to 74 years. Mean age was $52.88 \pm 11.88$. Risk factors such as smoking, hypertension, diabetes mellitus, dyslipidemia and F/H of CAD were evaluated. Highest percentage of study population had hypertension (52\%) followed by dyslipidemia (49\%), smoker $(46 \%)$, diabetes mellitus $(39 \%)$ and F/H of CAD had $(24 \%)$ of study population. There were five outcome variables such as heart failure, cardiogenic shock, arrhythmia, duration of hospital stay and death. Total 12 patients died. 10 patients died in Group-I and 2 patients died in Group-II. Among the outcome variables death, heart failure and hospital stay was more in Group-I and was statistically significant. Conclusion: Early developed hyponatremia in patients with ST-elevation acute myocardial infarction was an independent predictor of prognosis. Heart failure, duration of hospital stay and death was more in hyponatraemic patients and Prognosis worsen with increasing severity of hyponatremia. Plasma sodium level may serve as a simple marker to identify patient at high risk.

Keywords: Hyponatraemia, In- hospital outcome, Acute STEMI, Thrombolysis.

(Bangladesh Heart Journal 2017; 32(1) : 29-35)

1. Associate Professor, Department of Cardiology, Mymensingh Medical College and Hospital, Mymensingh, Bangladesh

2. MD (Thesis) Student, Department of Cardiology, Mymensingh Medical College and Hospital, Mymensingh, Bangladesh

3. Professor \& Head, Department of Cardiology, Anwer Khan Modern Medical College and Hospital, Dhaka, Bangladesh

Address of Correspondence: Dr. Mahmood Hasan Khan, MD (Thesis) Student, Department of Cardiology, Mymensingh Medical College and Hospital, Mymensingh, Bangladesh.

Email: drdipon@gmail.com; Mobile: +8801670025060
Introduction:

Coronary heart disease is a major cause of death and is a global health problem reaching epidemic in both developed as well as in developing countries ${ }^{1}$. It is the highest killer in developed countries and is rapidly assuming a similar role in developing ones. Globally, of those dying from cardiovascular diseases, 80 percent are in developing countries and not in the Western world. Coronary heart disease has been classified as chronic stable angina, acute coronary syndrome, (ACS) and sudden death. ACS encompasses different clinical

DOI: http://dx.doi.org/10.3329/bhj.v32i1.34167

Copyright $@ 2017$ Bangladesh Cardiac Society. Published by Bangladesh Cardiac Society. This is an Open Access articles published under the Creative Commons Attribution-NonCommercial 4.0 International License (CC BY-NC). This license permits use, distribution and reproduction in any medium, provided the original work is properly cited and is not used for commercial purposes. 
entities associated acute myocardial ischemia including ST segment elevation myocardial infarction (STEMI), nonST elevation myocardial infarction (NSTEMI) and unstable angina (UA). ${ }^{2}$

Acute STEMI continues to be a significant public health problem in industrialized Countries and is becoming an increasing by significant problem in developing countries $^{3}$.

Hyponatremia is a well-known electrolyte disorder in hospitalized patients and it can make the prognosis worse depending on their backgroundt $\{\mathrm{v}$. In congestive heart failure (CHF), hyponatremia is associated with exaggerated activation of baroreceptor-mediated hormones, including arginine vasopressin (AVP), catecholamines and the renin angiotensin-aldosterone systemv $\left\{{ }^{11}\right.$. In particular, the primary mechanism is dilutional hyponatremia triggered by osmolality independent secretion of AVP. Baroreceptor mediated hormonal release reflects the severity of heart failure, worsens cardiac remodeling in it-self, and thus could be one of the independent prognostic factors in CHFy. $9,12-17$

In patients with acute myocardial infarction (AMI), successful thrombolysis after acute STEMI, baroreceptormediated hormonal activation is similar to that in patients with CHF and has a prognostic value ${ }^{1} x\left\{{ }^{2} p\right.$. Hyponatremia, which developed in the early phase of AMI, has also been recently advocated as an important prognostic factor in several studies ${ }^{18,21}$

The prevalence and importance of hyponatremia in patients with ST elevation AMI (STEMI), however, have not yet been fully established. The present study had the aim to investigate the impact of hyponatremia on in hospital outcomes in patients who received successful thrombolysis after acute STEMI.

\section{Materials and Methods:}

This prospective observational study was carried out in the department of Cardiology, Mymensingh Medical College Hospital, Mymensingh during the period of July 2014 to June 2015, availing the laboratory facilities of the Mymensingh Medical College, Mymensingh. Purposive sampling was done using a structured case record form.

All patients with chest pain who were admitted into the Department of Cardiology of MMCH examined. With brief clinical history, target physical examination, ECG and Troponin-I the patients with first attack of Acute ST- segment elevation myocardial infarction were selected and thereby one hundred (100) patients who were eligible for thrombolysis were selected. Serum electrolyte of those patients were measured. The sample population was divided into two groups. Group-l: Patients with first attack of acute ST-Elevation myocardial infarction who developed hyponatraemia at 72 hours after admission. Group-II: Patients with first attack of Acute Myocardial Infarction who had normal sodium level at 72 hours after admission.

Group-I was further divided into 04 sub-groups according to the serum sodium levels. Group-la: Sodium level 130$134 \mathrm{~mm} / \mathrm{L}$, Group-lb: sodium level 125-129 mm/L, Group-lc: Sodium level 120-124 mm/L, Group-Id: Sodium level $<120 \mathrm{~mm} / \mathrm{L}$.

Selection of the study population was done on the basis of history taking and clinical examination of the patients and on some inclusion and exclusion criteria.

\section{Inclusion Criteria:}

Patients admitted into the Department of Cardiology with first attack of acute ST - elevation myocardial infarction treated by thrombolytic (Streptokinase).

\section{Exclusion Criteria:}

- Patient with valvular heart disease, congenital heart disease and cardiomyopathy.

- Patients who have major non cardiovascular disorder which causes hyponatraemia such as severe renal impairment, diarrhea and vomiting.

- Any systemic infection.

- Patient not willing to enroll in study.

- Patients who are not treated with thrombolytic agent after acute STEMI.

- Clinical conditions which causes syndrome of inappropriate ADH secretion (SIADH).

- Patients who have already hyponatraemia on admission.

Before examination a detailed briefing about the purpose of the study was given to the subjects and written consents were taken for all of the study population.

\section{Variables studied:}

Age, Sex, Smoking, Hypertension, Diabetes Mellitus, Dyslipidemia, F/H of CAD, Serum Electrolytes, Troponin-I, Heart failure, Arrhythmia like Atrial fibrillation, Ventricular tachycardia, Ventricular fibrillation, Cardiogenic Shock, Death.

The data were processed and analyzed by computer software SPSS (Statistical package for social science) Version 20. Level of significance was considered as $p$ value less than $0.05(p<0.05)$.

\section{Statistical Method and analysis:}

Continuous data were expressed as mean \pm SD. Categorical data were analyzed with $\mathrm{x}^{2}$ test. Student's t" test 
was used for analysis of continuous variables. Comparison between groups was done by unpaired t-test.

\section{Results:}

This was a prospective observational study conducted in the Cardiology department of Mymensingh Medical College Hospital for a period of one year from $1^{\text {st }}$ July 2014 to $30^{\text {th }}$ June 2015 . The main objective is to ascertain in-hospital outcome of early developed hyponatraemia in a setting of acute ST-elevation myocardial infarction treated by thrombolysis. Total sample population were 100. Group-I $(n=50)$ acute STEMI patient with hyponatraemia. Group-II $(n=50)$ Acute STEMI patient with normal sodium level.

Total of 100 patients were studied. The mean age of patient was $52.88 \pm 11.81$ ranging from 25 to 74 years. Majority of the patients were in 50 to 69 years of age but $12 \%$ patients were below 40 years. There was no statistically significant difference between the study groups $(p=0.765)$.

This table shows $85 \%$ patients were male and $15 \%$ were female. There was no statistically significant differences between the sex among the study population $(p=0.652)$.

The above table shows that HTN and Dyslipidaemia are the most prevalent risk factors among the study groups. Although smoking, diabetes and family history of CAD also had high prevalence but all were not statistically significant $(p>0.05)$.
Group-I Hyponatraemia (sodium level <135 mmol/L), Group -II (normal sodium level). Group -I further divided into 4 sub-groups.

Group-la: Sodium level 130-134 mmol/L, Group- Ib: Sodium level 125-129 mmol/L, Group-lc: Sodium level 120-124 mmol/L and Group-Id: Sodium level <120 $\mathrm{mmol} / \mathrm{L}$.

Table-4 shows division of Group-I patients according to plasma sodium level. Twenty eight patients (56\%) had sodium level $130-134 \mathrm{mmol} / \mathrm{L}$, fifteen patients $(30 \%)$ had sodium level $125-129 \mathrm{mmol} / \mathrm{L}$, five patients $(10 \%)$ had sodium level $120-124 \mathrm{mmol} / \mathrm{L}$ and two patients $(4 \%)$ had sodium level $<120 \mathrm{mmol} / \mathrm{L}$.

Table 5 shows outcome of study population according to serum sodium level. Heart failure occurred in $20 \%$ patients $(p=.003)$, arrhythmia developed in $23 \%$ patients $(p=0.107)$, cardiogenic shock occurred in $12 \%$ patients $(p=0.254)$ and death occurred in $12 \%$ patients $(p=0.002)$.

P-Value of heart failure and death was statistically significant.

Table 6 shows hospital stay /days of the study population according to serum sodium level. Group-l: two days $16 \%$, three days $36 \%$, four days $28 \%$ and five days were $20 \%$ patients. Group-II: 2 days $28 \%, 3$ days $56 \%, 4$ days $12 \%$ and 5 days were $4 \%$ patients $(p=0.001)$. It was statistically significant.

Table-I

Distribution of subjects by age $(n=100)$

\begin{tabular}{|c|c|c|c|c|c|c|c|}
\hline \multirow[t]{3}{*}{ Age in years } & \multicolumn{4}{|c|}{ Group } & \multirow{2}{*}{\multicolumn{2}{|c|}{ Total }} & \multirow[t]{3}{*}{$p$ - Value } \\
\hline & \multicolumn{2}{|c|}{ Group-I $(n=50)$} & \multicolumn{2}{|c|}{ Group-II $(n=50)$} & & & \\
\hline & No. & $\%$ & No. & $\%$ & No. & $\%$ & \\
\hline$<30$ & 3 & $6.0 \%$ & 1 & $2.0 \%$ & 4 & $4.0 \%$ & \\
\hline $30-39$ & 3 & $6.0 \%$ & 5 & $10.0 \%$ & 8 & $8.0 \%$ & \\
\hline $40-49$ & 8 & $16.0 \%$ & 14 & $28.0 \%$ & 22 & $22.0 \%$ & \\
\hline $50-59$ & 18 & $36.0 \%$ & 12 & $24.0 \%$ & 30 & $30.0 \%$ & \\
\hline $60-69$ & 13 & $26.0 \%$ & 12 & $24.0 \%$ & 25 & $25.0 \%$ & \\
\hline e"70 & 5 & $10.0 \%$ & 6 & $12.0 \%$ & 11 & $11.0 \%$ & \\
\hline Total & 50 & $100.0 \%$ & 50 & $100.0 \%$ & 100 & $100.0 \%$ & \\
\hline Mean \pm SD & \multicolumn{2}{|c|}{$53.52 \pm 11.58$} & \multicolumn{2}{|c|}{$52.24 \pm 12.11$} & \multicolumn{2}{|c|}{$52.88 \pm 11.81$} & 0.765 \\
\hline
\end{tabular}

Table-II

Sex Distribution of the study group $(n=100)$

\begin{tabular}{|c|c|c|c|c|c|c|c|}
\hline \multirow[t]{3}{*}{ Sex } & \multicolumn{4}{|c|}{ Group } & \multirow{2}{*}{\multicolumn{2}{|c|}{ Total }} & \multirow{3}{*}{$\begin{array}{r}\text { p- Value } \\
0.652\end{array}$} \\
\hline & \multicolumn{2}{|c|}{ Group-I $(n=50)$} & \multicolumn{2}{|c|}{ Group-II $(n=50)$} & & & \\
\hline & Frequency & $\%$ & Frequency & $\%$ & Frequency & $\%$ & \\
\hline Male & 42 & 84.0 & 43 & 86.0 & 85 & 85.0 & \\
\hline Female & 8 & 16.0 & 7 & 14.0 & 15 & 15.0 & \\
\hline
\end{tabular}


Table-III

Distribution of the study subject by risk factors $(n=100)$

\begin{tabular}{|c|c|c|c|c|c|c|c|}
\hline & \multicolumn{2}{|c|}{ Group I } & \multicolumn{2}{|c|}{ Group II } & \multirow[b]{2}{*}{ Total } & \multirow[b]{2}{*}{ P-value } & \multirow[b]{2}{*}{ Sig } \\
\hline & Frequency & $\%$ & Frequency & $\%$ & & & \\
\hline Smoking & 24 & $48 \%$ & 22 & $44 \%$ & 46 & 0.455 & NS \\
\hline HTN & 27 & $54 \%$ & 25 & $50 \%$ & 52 & 0.547 & NS \\
\hline DM & 22 & $44 \%$ & 17 & $34 \%$ & 39 & 0.222 & NS \\
\hline Dyslipidemia & 26 & $52 \%$ & 23 & $46 \%$ & 49 & 0.382 & NS \\
\hline Family F/H of CAD & 14 & $28 \%$ & 10 & $20 \%$ & 24 & 0.300 & NS \\
\hline
\end{tabular}

Group-l: Patients with hyponatraemia.

Group-II: Patients with normal sodium level.

P-value obtained by Chi-square test

Table-IV

Distribution of Group-I by serum sodium level $(n=50)$

\begin{tabular}{lcc}
\hline $\mathrm{Na}^{+}$Level & \multicolumn{2}{c}{ Group-l } \\
\cline { 2 - 3 } & Frequency & $\%$ \\
\hline Group la $\left(\mathrm{Na}^{+} 130-134 \mathrm{mmol} / \mathrm{L}\right)$ & 28 & 56.0 \\
Group Ib $\left(\mathrm{Na}^{+} 125-129 \mathrm{mmol} / \mathrm{L}\right)$ & 15 & 30.0 \\
Group Ic $\left(\mathrm{Na}^{+} 120-124 \mathrm{mmol} / \mathrm{L}\right)$ & 5 & 10.0 \\
Group Id $\left(\mathrm{Na}^{+}<120 \mathrm{mmol} / \mathrm{L}\right)$ & 2 & 4.0 \\
\hline Total & 50 & 100.0 \\
\hline
\end{tabular}

Significant at $1 \%$ level of probability $(p<0.01)$

Table-V

Distribution of the subject by in-hospital outcome $(n=100)$

\begin{tabular}{|c|c|c|c|c|c|c|c|c|c|c|c|c|c|c|}
\hline \multirow[t]{3}{*}{ Outcome } & & \multicolumn{11}{|c|}{$\mathrm{Na}^{+}$Level } & \multirow[b]{3}{*}{$P$ value } & \multirow[b]{3}{*}{ Sig } \\
\hline & & \multicolumn{2}{|c|}{$\begin{array}{c}\left(\mathrm{Na}^{+} 130-134\right. \\
\mathrm{mmol} / \mathrm{L})\end{array}$} & \multicolumn{2}{|c|}{$\begin{array}{c}\left(\mathrm{Na}^{+} 125-129\right. \\
\mathrm{mmol} / \mathrm{L})\end{array}$} & \multicolumn{2}{|c|}{$\begin{array}{c}\left(\mathrm{Na}^{+} 120-124\right. \\
\mathrm{mmol} / \mathrm{L})\end{array}$} & \multicolumn{2}{|c|}{$\begin{array}{c}\left(\mathrm{Na}^{+}<120\right. \\
\mathrm{mmol} / \mathrm{L})\end{array}$} & \multicolumn{2}{|c|}{$\begin{array}{c}\left(\mathrm{Na}^{+}>135\right. \\
\mathrm{mmol} / \mathrm{L})\end{array}$} & \multirow[b]{2}{*}{ Total } & & \\
\hline & & Frequency & $\%$ & Frequency & $\%$ & Frequency & $\%$ & Frequency & $\%$ & Frequency & $\%$ & & & \\
\hline \multirow[t]{2}{*}{ Heart Failure } & Yes & 6 & 21.4 & 5 & 33.3 & 2 & 40.0 & 1 & 50.0 & 6 & 12.0 & 20 & 0.003 & ** \\
\hline & No & 22 & 78.6 & 10 & 66.7 & 3 & 60.0 & 1 & 50.0 & 44 & 88.0 & 80 & & \\
\hline \multirow[t]{2}{*}{ Arrhythmia } & Yes & 7 & 25.0 & 5 & 33.3 & 2 & 40.0 & 1 & 50.0 & 8 & 16.0 & 23 & 0.107 & NS \\
\hline & No & 21 & 75.0 & 10 & 66.7 & 3 & 60.0 & 1 & 50.0 & 42 & 84.0 & 77 & & \\
\hline \multirow[t]{2}{*}{ Cardiogenic shock } & Yes & 4 & 16.6 & 3 & 20.0 & 2 & 40.0 & 1 & 50.0 & 2 & 4.0 & 12 & 0.254 & NS \\
\hline & No & 24 & 83.3 & 12 & 80.0 & 3 & 60.0 & 1 & 50.0 & 48 & 96.00 & 88 & & \\
\hline \multirow[t]{2}{*}{ Death } & Yes & 2 & 7.1 & 5 & 33.3 & 2 & 40.0 & 1 & 50.0 & 2 & 4.0 & 12 & 0.002 & ** \\
\hline & No & 26 & 92.9 & 10 & 66.7 & 3 & 60.0 & 1 & 50.0 & 48 & 96.0 & 88 & & \\
\hline
\end{tabular}

** $=$ Significant at $1 \%$ level of probability $(p<0.01)$

NS $=$ Not significant $(p>0.05)$

Table-VI

Distribution of study subject by duration of hospital stay $(n=100)$

\begin{tabular}{|c|c|c|c|c|c|c|c|c|c|c|c|c|}
\hline \multirow{3}{*}{$\begin{array}{l}\text { Hospital } \\
\text { Stay/day }\end{array}$} & \multicolumn{10}{|c|}{$\mathrm{Na}^{+}$Level } & \multirow{3}{*}{$\mathrm{P}$ value } & \multirow{3}{*}{ Sig. } \\
\hline & \multicolumn{2}{|c|}{$\begin{array}{c}\left(\mathrm{Na}^{+} 130-134\right. \\
\mathrm{mmol} / \mathrm{L})\end{array}$} & \multicolumn{2}{|c|}{$\begin{array}{c}\left(\mathrm{Na}^{+} 125-129\right. \\
\mathrm{mmol} / \mathrm{L})\end{array}$} & \multicolumn{2}{|c|}{$\begin{array}{c}\left(\mathrm{Na}^{+} 120-124\right. \\
\mathrm{mmol} / \mathrm{L})\end{array}$} & \multicolumn{2}{|c|}{$\begin{array}{c}\left(\mathrm{Na}^{+}<120\right. \\
\mathrm{mmol} / \mathrm{L})\end{array}$} & \multicolumn{2}{|c|}{$\begin{array}{c}\left(\mathrm{Na}^{+}>135\right. \\
\mathrm{mmol} / \mathrm{L})\end{array}$} & & \\
\hline & Frequency & $\%$ & Frequency & $\%$ & Frequency & $\%$ & Frequency & $\%$ & Frequency & $\%$ & & \\
\hline 2.00 & 5 & 17.9 & 3 & 20.0 & 0 & 0.0 & 0 & 0.0 & 14 & 28.0 & & \\
\hline 3.00 & 13 & 46.4 & 2 & 13.3 & 3 & 60.0 & 0 & 0.0 & 28 & 56.0 & 0.001 & ** \\
\hline 4.00 & 7 & 25.0 & 6 & 40.0 & 1 & 20.0 & 0 & 0.0 & 6 & 12.0 & & \\
\hline 5.00 & 3 & 10.7 & 4 & 26.7 & 1 & 20.0 & 2 & 100.0 & 2 & 4.0 & & \\
\hline Total & 28 & 100.0 & 15 & 100.0 & 5 & 100.0 & 2 & 100.0 & 50 & 100.0 & & \\
\hline
\end{tabular}




\section{Discussion:}

Total 100 patients of acute ST-Elevation Myocardial Infarction were selected for the study. Patients admitted in $\mathrm{CCU}$ in $\mathrm{MMCH}$ with first attack of acute STEMI were evaluated for hyponatraemia.

Among the base line characteristics age range were 25 to 74 years, mean age $52.88 \pm 11.81$ years. The difference between the age groups were statistically non-significant. $85 \%$ were male and $15 \%$ were female. The difference between the age groups were statistically non-significant. Male and female ratio was 5.6: 1. Rahman et al., 1999 found in their study that $13.3 \%$ were female. The observations of our study was quite similar to the other studies.

Among the important risk factors the prevalence of smoking (46\%), hypertension (52\%), diabetes mellitus (39\%), dyslipidemia (49\%) and family history of coronary disease (24\%). But they were statistically non-significant.

In hyponatremic patients (Group -I) 44\% patients were diabetic, where as diabetes was $34 \%$ among the patients with normal sodium level (Group-II). In Group-I patients $48 \%$ had history of smoking habit. In a previous study smoking habit was found $37 \%$ among the patient with hyponatraemia in setting of acute ST-Elevation MI. Hypertension were present $54 \%$ among the study population. In previous study it was $44 \%^{21}$.

In this study total of 12 patients (12\%) died. Another study in 1999 it was found that hospital mortality was $22.5 \%$. A study in 1982 found $20 \%$ mortality rate in their study with MI. In patient with normal sodium level death occurred in 2 patients (4\%) and death occurred in patient with hyponatraemia 10 patients $(20 \%),(P=0.002)^{22}$. In this study mortality decreases may be due to early detection and management of hyponatraemia.

Hyponatraemic patients were categorized in to four groups, one patient $(50 \%)$ out of 2 patients died with plasma sodium level $<120 \mathrm{mmol} / \mathrm{L}$. In patients with plasma sodium level $120-124 \mathrm{mmol} / \mathrm{L}$ death occurred in 2 patients $(40 \%)$ out of 5 patients in this group. 5 patients (33.3\%) died out of 15 patients in sodium level 125-129 $\mathrm{mmol} / \mathrm{L}$. Death occurred in 2 patients $(7.1 \%)$ out of 28 patients having serum sodium level $130-134$. So mortality increased with increasing severity of hyponatraemia compared with patients having normal sodium level. Chi -square test and multivariate regression analysis on mortality was significantly higher among Group-I compared with Group- II.

A study in 1979 showed in their study that relation of mortality and plasma sodium level. $7 \%$ died with normal plasma sodium level, $17 \%$ with sodium level $135-130$ $\mathrm{mmol} / \mathrm{L}$ and $22 \%$ died with plasma sodium level less than $130 \mathrm{mmol} / \mathrm{L}^{23}$.

In acute STEMI patients without hyponatraemia had a mortality rate $6.2 \%{ }^{22}$. Patients with hyponatraemia on admission mortality rate were $19.8 \%$ and $16.8 \%$ in patients who developed hyponatraemia after admission. After logistic regression analysis and adjustment for other important co-variants they concluded that both hyponatraemia on admission and hyponatraemia developing after admission remained strong independent predictor of 30 -day mortality.

In our study adverse hospital outcome other than mortality included heart failure, arrhythmia, cardiogenic shock and duration of hospital stay. Heart failure developed in $20 \%$ patients. Another study found that $22.7 \%$ patients developed heart failure ${ }^{2}$. Sixteen (32\%) developed heart failure in Group-l and Six patients (12\%) in Group-II. Heart failure developed in highest percentage in patients with sodium level $<120 \mathrm{mmol} / \mathrm{L}$. So there was a relation between hyponatraemia and developing heart failure that was increasing with increased severity of hyponatraemia.

Arrhythmia developed in this study was $23 \%$. Rahman et al., 1999 found occurrence of arrhythmia increased with increasing the degree of hyponatraemia

A study found that episodes of ventricular fibrillation occurred in relation to sodium level. They got significant ventricular fibrillation in patient with sodium level 132 $\mathrm{mmol} / \mathrm{L}$ and got no arrhythmia in patients with normal sodium level ${ }^{23}$.

Cardiogenic shock occurred in twelve patients $(12 \%)$ of study population, 10 patients $(20 \%)$ in hyponatraemic and 2 patients $(4 \%)$ in patients with normal Sodium level. p-value was 0.254 , was statistically non- significant.

Duration of hospital stay of the study population according to serum sodium level was statistically significant.

Total 12 patients died, among them 10 patients died in Group-I and 2 patients died in Group-II. Mortality increased with increasing severity of hyponatraemia. It was statistically significant. Other study also concluded that mortality increased with degree of hyponatraemia ${ }^{22}$.

\section{Limitations}

Several limitations of our study must be acknowledged:

- Study population was small.

- Study was single centered.

\section{Conclusion:}

This study was done to find out the prognostic implication of hyponatraemia in the setting of STEMI. Observations 
were done to find out the in-hospital outcome of hyponatraemic patients and patients with normal sodium level at 72 hours after acute ST-elevation myocardial infarction treated by thrombolysis. Among the parameters of outcome, heart failure, hospital stay and death was statistically significant but arrhythmia and cardiogenic shock was not significant. This study concluded that heart failure, hospital stay and death occur more in hyponatremic patients than patients with normal sodium level and increasing disease severity with increasing severity of hyponatraemia. So early developed hyponatraemia in patients with ST-elevation acute myocardial infarction treated by thrombolysis considered to be an important predictor of prognosis.

\section{Recommendations}

Early developed hyponatraemia in patients with acute ST-elevation myocardial infarction is an important predictor of prognosis. Prognosis worsen with increasing severity of hyponatraemia. Facilities of plasma sodium measurement is available in most of the hospitals and is a non-invasive procedure. By early detection of serum sodium level we can identify the patients at high risk.

\section{References}

1. Chaturvedi V, Bhargava B. Health care delivery for coronary heart disease in India where are we headed? Am Heart Hosp J 2007; 5: 32-7.

2. Kim MC, Kini AS, Fuster V. Definition of acute coronary syndromes. In: Fuster V, Walsh RA, Harrington RA, $13^{\text {th }}$ ed. Hurst's The Heart. New York: McGraw Hill, 2011. pp. 1287-95.

3. Rogers WJ, Canto JG, Lambrew CT. Temporal trends in the treatment of over 1.5 million patients with myocardial infarction in the US from 1990 through 1999: National Registry of myocardial infarction 1, 2 and 3. J Am Coll Cadiol 2000; 36: 2056-63.

4. Clayton JA, Le Jeune IR, Hall IP. Severe hyponatraemia in medical in-patients: Aetiology, assessment and outcome. QJM 2006; 99: 505-11.

5. Upadhyay A, Jaber BL, Madias NE. Incidence and prevalence of hyponatremia. Am Med J 2006; 119: S30-5.

6. Nakamura T, Funayama H, Yoshimura A. Possible vascular role of increased plasma arginine vasopressin in congestive heart failure. Int $\mathrm{J}$ Cardiol 2006; 106:191-5.
7. Schrier RW. Body fluid volume regulation in health and disease: a unifying hypothesis, Ann Intern Med 1990; 113:155-9.

8. Riegger GA, Liebau G, Kochsiek K. Antidiuretic hormone in congestive heart failure. Am J Med 1982; $72: 49-52$.

9. Szatalowiscz VL, Arnold PE, Chaimovitz C. Radioimmunoassay of plasma arginine vasopressin in hyponatremic patients with congestive heart failure. N Engl J Med 1981; 305:263-6.

10. Goldsmith SR, Francis GS, Cowley AW Jr. Increased plasma arginine vasopressin levels in patients with congestive heart failure. J Am Coll Cardiol 1983; $1: 1385-90$

11. Pruszczynski W, Vahanian A, Ardaillou R. Role of antidiuretic hormone in impaired water excretion of patients with congestive heart failure. J Clin Endocrinol Metab 1984; 58:599 - 605.

12. Lee $\mathrm{WH}$, Packer M. Prognostic importance of serum sodium concentration and its modification by converting -enzyme inhibition in patients with severe chronic heart failure. Circulation 1986; 73 : 257-67.

13. Saxon LA, Stevenson WG, Middlekauff HR. Predicting death from progressive heart failure secondary to ischemic or idiopathic dilated cardiomyopathy. Am J Cardiol 1993; 72: 62-5.

14. Kumar S, Berl T. Sodium. Lancet 1998; 352: 220-8.

15. Rossi J, Bayram M, Udelson JE. Improvement in hyponatremia during hospitalization for worsening heart failure is associated with improved outcomes: Insights from the Acute and Chronic Therapeutic Impact of a Vasopressin Antagonist in Chronic Heart Failure (ACTIV in CHF) trial. Acu Card Care 2007; 9:82-6.

16. Packer M. The neurohormonal hypothesis: A theory to explain the mechanism of disease progression in heart failure. J Am Coll Cardiol 1992; 20: 24854.

17. Ferrari R, Ceconi C, Campo G. Mechanisms of remodeling: A question of life (stem cell production) and death (myocyte apoptosis). Circulation 2009; 73:1973-82.

18. Goldberg A, Hammerman H, Petcherski S. Hyponatremia and long-term mortality in survivors 
of acute ST-elevation myocardial infarction. Arch Intern Med 2006; 166:781-6.

19. Rouleau JL, de Champlain J, Klein M. Activation of neurohumoral systems in postinfarction left ventricular dysfunction. J Am Coll Cardiol 1993; 22:390-8.

20. Rouleau JL, Packer M, Moye L. Prognostic value of neurohumoral activation in patients with an acute myocardial infarction: Effect of captopril. J Am Coll Cardiol 1994; 24:583-91.

21. Singla I, Zahid M, Good CB. Effect of hyponatremia $(<135 \mathrm{mEq} / \mathrm{L})$ on outcome in patients with non-ST elevation acute coronary syndrome. Am J Cardiol 2007; 100: 406-8.

22. Alexander G, Haim H, Sirouch P. Abstract of Prognostic importance of hyponatremia in acute ST elevation myocardial infarction, Circulation 2003; 108 (18):2212-8.

23. Flear $\mathrm{CT}$, Hilton P. Hyponatraemia and severity and outcome of myocardial infarction, BMJ 1979; 1 : 1242-6.

24. Subash CD, Zaher A, Mamtaz H. Clinical profile of acute $\mathrm{MI}$ cases admitted in CCU of Chittagong Medical College Hospital. Bangladesh Heart Journal 1992; 7: 49-52. 